\title{
MODEL PEMBELAJARAN PENDIDIKAN AGAMA ISLAM DALAM PEMBINAAN MENTAL NARAPIDANA (STUDI MULTIKASUS DI LEMBAGA PEMASYARAKATAN KELAS I MALANG DAN LEMBAGA PEMASYARAKATAN WANITA KELAS II-A MALANG)
}

\author{
Muhammad Fauzy Emqi ${ }^{1}$
}

\begin{abstract}
Abstrak
Replacement of the term "prison" to "Correctional Institute "of course if you lack good intentions, the administration and guardianship prisoners are not only focused on the good faith judgment alone, but more oriented actions are more humane and adapted to the conditions of prisoners it. Special education functions carried out in prisons, lies in the function to which it aspires, namely the implementation of porses awareness and readjustment of the prisoner (the people who have committed violations of law, not ordinary people), so they do not violate legal provisions and norms adopted society. Both Correctional Institute has also got ISO 9001:2008, for being able to provide good services to the inmates.

The results showed that: Based on exposure data and discussion of the above results, it can be concluded that: (1) Islamic Educational material delivered to inmates in Malang Correctional Institute Class I and Women Correctional Institute Class II-A Malang is about faith (monotheism), and morals, (2) model of Islamic education in mental development of prisoners conducted in Malang Correctional Institute Class I and Women Correctional Institute Class II-A Malang is a model of behavior modification. (3) mental state inmates after holding the Islamic education learning models in Correctional Institute Class I Malang and Women Correctional Institute Class II-A Malang.
\end{abstract}

Keywords: Learning model, Islamic education learning, Mental development

\section{A. Pendahuluan}

Penggantian istilah "penjara" menjadi "Lembaga Pemasyarakatan" tentu mengandung maksud baik, yaitu pemberian maupun pengayoman warga binaan tidak hanya terfokus pada itikad menghukum (Funitif

1 Dosen Pendidikan Agama Islam Fakultas Ekonomi Universitas Tribhuwana Tunggadewi Malang 
Intend) saja melainkan suatu berorientasi pada tindakan-tindakan yang lebih manusiawi dan disesuaikan dengan kondisi dari warga binaan itu. Walau istilah pemasyarakatan sudah muncul pada tanggal 5 Juli 1963, namun prinsip-prinsip mengenai pemasyarakatan itu baru dilembagakan setelah berkembangnya konferensi Bina Direktorat Pemasyarakatan di Lembang, Bandung (Jawa Barat) tanggal 27 April 1964 dan dari hasil konferensi dapat disimpulkan bahwa: Tujuan dari pidana penjara bukanlah hanya untuk melindungi masyarakat semata-mata, melainkan harus pula berusaha membina si pelanggar hukum, dimana pelanggar hukum tidak lagi disebut sebagai penjahat dimana seorang yang tersesat akan selalu bertobat dengan harapan dapat mengambil manfaat sebesar-besarnya dari sistem pemahaman yang diterapkan kepadanya.

Pemasyarakatan dinyatakan sebagai suatu sistem pembinaan terhadap para pelanggar hukum dan sebagai suatu keadilan yang bertujuan untuk mencapai reintegrasi sosial atau pulihnya kesatuan hubungan antara warga binaan pemasyarakatan dengan masyarakat. Beberapa contoh jenis kejahatan yang dilakukan oleh narapidana yang masuk ke dalam Lapas diantaranya adalah kasus korupsi, kesusilaan, perjudian, pembunuhan, pencurian, penipuan dan Narkoba. (Dokumen resmi, 2012)

Pembinaan kepada narapidana bertujuan untuk memberikan seperangkat bekal hidup, baik bekal pengetahuan, keterampilan, maupun bekal mental spiritual untuk menambahkan kesadaran mereka, sehingga dapat dan mampu menjadi warga masyarakat Indonesia yang baik dan berguna, serta tanpa diasingkan oleh warga masyarakat lainnya dalam menjalani kehidupannya. Sesuai dengan UU Republik Indonesia Nomor 12 tahun 1995 Bab II Pasal 5 huruf c dan d, dijelaskan bahwa yang dimaksud dengan "pendidikan dan pembimbingan" adalah bahwa penyelenggaraan pendidikan dan bimbingan dilaksanakan berdasarkan Pancasila, antara lain penanaman jiwa kekeluargaan, keterampilan, pendidikan kerohanian dan kesempatan untuk menunaikan ibadah. (UU Republik Indonesia Nomor 12 tahun 1995 Bab II Pasal 5 huruf c dan d)

Fungsi pendidikan khusus yang dilaksanakan di Lapas, terletak pada fungsi yang diembannya, yaitu penyelenggaraan porses penyadaran dan readjustment bagi para napi (orang-orang yang pernah melakukan pelanggaran hokum, bukan orang biasa), agar mereka tidak melanggar 
ketetapan hukum dan norma-norma yang dianut masyarakat. Karena yang menjadi tujuan lembaga ini adalah perubahan sifat, serta perilaku, proses interaksi edukatif harus dibangun. Dengan kata lain, jenis dan proses interaksi yang dikembangkan, baik yang dilakukan antara sesama sipir, napi dan petugas lain, harus bersifat mendidik, memenuhi prinsip kejujuran, keadilan dan kemanusiaan. Interaksi edukatif yang intensif sangat diperlukan, agar secara kolektif tumbuh kesadaran dari para napi tentang perilaku yang seharusnya dilakukan. (David J. Cooke, 2008: xiv)

Kendati demikian, tataran ideal yang dilaksanakan di dalam lapas sering kali berbeda dengan realitas. Keadaan LP di Indonesia pada umumnya masih jauh dari yang diharapkan. Saat ini, kehidupan dalam LP masih diliputi kesemrawutan. Alih-alih terjadi interaksi edukatif, yang banyak ditemukan di dalam LP justru kehidupan sebaliknya. LP masih dikotori dengan segala macam praktik tidak tepuji, seperti perlakuan diskrimatif, penyuapan, pemerasan dan tindak kekerasan. (David J. Cooke, 2008: xiv)

Pembinaan mental spiritual yang seharusnya memberikan penghayatan dan penyadaran keagamaan terhadap narapidana, seakan-akan hanyalah formalitas belaka dan tidak memberikan efek jera terhadap narapidana. Menurut Kriminolog Universitas Indonesia, Adrianus Meliala, fenomena kian beringasnya residivis, merupakan dampak faktor psikologis dan sosiologis. Residivis memang selalu dalam kondisi yang gamang dan goyah, mereka tidak mempunyai keyakinan untuk beradapatasi dengan masyarakat. Pembinaan di lapas tidak menjamin residivis berbuat kejahatan kembali. Begitu keluar, narapidana menikmati kembali kebebasan dan merasa lebih jago karena telah bergaul dan banyak belajar dari penjahat di LP, sehingga ingin menunjukkan kepada teman-temannya dengan berbuat jahat. Residivis cenderung akan kembali melakukan kejahatan karena kesulitan bersosialisasi dengan masyarakat. Menurut beliau, lingkungan yang tidak dapat menerima status residivis membuatnya kembali kepada kelompok yang mendorongnya berbuat kejahatan.

\section{B. Fokus Penelitian}

Berdasarkan konteks penelitian di atas, maka permasalahan yang dapat dirumuskan meliputi: 
1. Apa materi pendidikan agama Islam dalam pembinaan mental narapidana di Lembaga Pemasyarakatan Klas I dan Lembaga Pemasyarakatan Wanita Klas II-A Malang?

2. Bagaimana model pembelajaran pendidikan agama Islam dalam pembinaan mental narapidana di Lembaga Pemasyarakatan Klas I dan Lembaga Pemasyarakatan Wanita Klas II-A Malang?

3. Bagaimana kondisi mental narapidana di LP Klas I Malang dan LP Wanita Klas II-A Malang?

\section{Model Pembelajaran Pendidikan Agama Islam}

Model adalah implikasi dari suatu sistem yang menggambarkan keadaan yang sebenarnya. Dalam arti luas, model merupakan pengembangan sebagian dari kenyataan melalui beberapa fase pada suatu bidang ilmu pengetahuan. adalah pola dari sesuatu yang akan dibuat atau dihasilkan. Model juga dapat diartikan sebagai sesuatu yang dianggap benar, tetapi bersifat kondisional. (Muhaimin, 2001: 305) Sedangkan dalam sebuah pembelajaran, suatu model berawal dari pendekatan yang dijadikan titik tolak atau sudut pandang terhadap proses pembelajaran. Dari pendekatan pembelajaran yang telah ditetapkan selanjutnya diturunkan ke dalam strategi pembelajaran. Strategi pembelajaran sifatnya masih konseptual dan untuk mengimplementasikannya digunakan berbagai metode pembelajaran tertentu. Dengan kata lain, strategi merupakan plan of operation achieving something, sedangkan metode adalah a way in achiving something. Selanjutnya metode pembelajaran dijabarkan ke dalam teknik dan gaya pembelajaran.

Untuk lebih memperjelas tentang model pembelajaran pendidikan agama Islam dalam pembinaan mental narapidana, maka perlu dijelaskan terlebih dahulu tentang model pembelajaran secara umum. Menurut Bruce Joyce dan Marsha Weil, ada 4 kelompok model pembelajaran, yaitu:

1. Model Interaksi Sosial

Model interaksi sosial menekankan pada hubungan personal dan sosial kemasyarakatan diantara warga binaan. Model tersebut berfokus pada peningkatan kemampuan warga binaan. untuk berhubungan dengan orang lain, terlibat dalam proses-proses yang demokratis dan bekerja secara 
produktif dalam masyarakat. Model ini didasari oleh teori belajar Gestalt (field-theory). Model interaksi sosial menitikberatkan pada hubungan yang harmonis antara individu dengan masyarakat (learning to life together).

Pokok pandangan Gestalt adalah objek atau peristiwa tertentu akan dipandang sebagai suatu keseluruhan yang terorganisasikan. Makna suatu objek/peristiwa adalah terletak pada keseluruhan bentuk (Gestalt) dan bukan bagian-bagiannya. Pembelajaran akan lebih bermakna bila materi diberikan secara utuh bukan bagian-bagian.

Aplikasi teori Gestalt dalam pembelajaran mengacu pada beberapa aspek yaitu, pengalaman insight, pembelajaran yang bermakna, perilaku bertujuan dan prinsip ruang hidup (Life space).

Model-model pengajaran yang disajikan muncul karena adanya suatu anggapan mengenai tabiat dasar manusia sebagai makhluk sosial dan cara-cara mereka belajar. (Bruce Joyce, 2009: 295) Mereka juga juga percaya bahwa sebuah usaha yang dilakukan bersama pada dasarnya dapat meningkatkan kualitas kehidupan, mendatangkan kebahagiaan dan semangat serta supple dan mencegah adanya konflik sosial yang dekonstruktif. (Bruce Joyce, 2009: 295)

\section{Model Pengolahan Informasi}

Menekankan proses pembentukan tingkah laku dalam hal cara - cara memperoleh dan mengorganisir data, memikirkan dan memecahkan masalah, serta penggunaan simbol verbal/bahasa. Model pemprosesan Informasi menekankan pada aspek kecakapan pelajar untuk memecahkan masalah, dan menekankan aspek berfikir yang produktif, sedangkan beberapa yang lainnya lebih menekankan kecakapan intelektual umum. (AM Alim Sumarno, 2011)

\section{Model Personal Humanistik}

Menekankan proses pengembangan pribadi dan berusaha menggalakkan kemandirian yang produktif sehingga semakin sadar dan bertanggung jawab kepada dirinya. Beberapa model pembelajaran yang tergolong didalamnya adalah pengajaran tanpa arahan, pertemuan kelas dan latihan kesadaran. (Bruce Joyce, 2009: 116) 
4. Model Modifikasi Tingkah Laku

Menekankan pada perilaku yang terobservasi metode bagaimana memanipulasi penguatan atau reinforcement. Menekankan pada aspek perubahan perilaku psikologis dan perilaku yang tidak dapat di amati. Salah satu karakteristik umum pada model - model perilaku adalah dalam hal penjabaran tugas - tugas yang harus dipelajari menjadi serangkaian perilaku dalam bentuk yang lebih rinci dan berurutan. (Bruce Joyce, 2009: 116)

Untuk menerapkan sistem perilaku, seseorang tidak harus menerima gagasan bahwa semua perilaku dibentuk oleh variable lingkungan. Meski terkadang memang begitu. Misalkan saja, kita bisa menggunakan sikap para behavioris dalam membangun simulasi-simulasi warga binaan yang berinteraksi dengan simulasi ini mempelajari suatu hal yang secara simultan, mereka menerima posisi personal yang bisa mengarahkan mereka untuk memilih dan memiliki perilaku mereka sendiri. (Bruce Joyce, 2009: 401)

\section{Mental}

MenurutZakiah Daradjat, kesehatan mental adalah bentuk personifikasi iman dan takwa. Bila kesehatan mental berbicara tentang integritas kepribadian, realisasi diri, aktualisasi diri, penyesuaian diri dan pengendalian diri, maka parameternya harus merujuk pada iman dan takwa, akidah dan syariat. Dilibatkannya unsur iman dan takwa dalam teori kesehatan mental itu bertopang pada suatu kenyataan, bahwa tidak sedikit ditemukan orang yang tampaknya hidup sejahtera dan bahagia akan tetapi sebenarnya jiwanya gersang dan stres lantaran dia tidak taat beragama. (Kholil Lur Rahman, 2010: 13)

Adalah suatu kenyataan bahwa kesehatan mental berhubungan dengan berbagai segi kesejahteraan masyarakat seperti kemiskian, pendidikan, pekerjaan dan perumahan. Misalnya kemiskian dapat membuat kesejahteraan masyarakat terganggu sehingga mengakibatkan terganggunya kesehatan mental. Banyak kasus bunuh diri disebabkan bukan saja karena frustasi tetapi juga karena kemiskinan dan kurangnya tingat pendidikan yang dimiliki seseorang. Untuk mengatasi masalah ini agama dapat membantu 
manusia mencapai kesejahteraan dan kebahagiaan. Agama membimbing manusia mencapai kebaikan dan kebahagiaan di dunia dan akhirat. (Kholil Lur Rahman, 2010: 20-21)

Kesehatan mental diperlukan bagi setiap orang yang merindukan ketentraman dan kebahagiaan. Kesehatan mental tidak hanya memanifestasikan diri dalam menampakkan tanda-tanda tanpa adanya gangguan batin saja, akan tetapi posisi pribadinya juga harmonis dan baik, selaras dengan dunia luar dan di dalam dirinya dan baik pula harmonis pula dengan lingkungannya. Dengan demikian, orang yang sehat mentalnya itu secara mudah bisa melakukan adaptasi (penyesuaian diri), selalu aktif berpartisipasi, bisa menerapkan diri dengan lancar pada setiap perubahan sosial, selalu baik melaksanakan realisasi diri dan senantiasa dapat menikmati kepuasan dalam pemenuhan kebutuhan-kebutuhannya. (Kholil Lur Rahman, 2010: 54)

Inti utama masalah kesehatan mental menurut Islam adalah bagaimana menumbuhkembangkan sifat-sifat terpuji serta sekaligus menghilangkan sifat-sifat tercela pada pribadi seseorang. Dalam Islam sifat-sifat mahmudah adalah sifat ilahiyah dan sifat-sifat madzmumah adalah sifat syaitaniyah. Demikian juga pandangan Islam terhadap kesehatan mental antara lain dapat dilihat peran agama Islam sendiri bagi kehidupan manusia, agama Islam memberikan tugas dan tujuan bagi kehidupan manusia di dunia dan di akhirat. (Kholil Lur Rahman, 2010: 53-54)

Dalam menggali hikmah dari pengalaman keberagamaan yang pernah dialami oleh seseorang, sebenarnya tidak hanya terbatas pada akal pikiran, yang menjadi pengendali utama dalam sikap, tindakan dan perbuatan seseorang dalam menjalani kehidupan, namun juga perasaan. Telah terbukti bahwa tidak selamanya perasaan tunduk kepada pikiran, bahkan seringkali terjadi sebaliknya, pikiran tunduk kepada perasaan. (Zakiah Drajat, 1971:10)

\section{E. Lembaga Pemasyarakatan}

Merujuk pada pendapat R.A. Kosnoen, SH., istilah penjara berasal bahasa jawa penjoro, yang berarti tobat. Sementara Bahroedin Soejobroto menyebutkan kata penjara berasal dari kata penjera. Kedua pemahaman 
tersebut menyiratkan penjara sebagai tempat menghukum untuk membuat jera dan menanamkan rasa takut masyarakat agar tidak menentang penjajah koloni Belanda. (Muchtar Papahan, 2011)

Penggantian istilah "penjara” menjadi "Lembaga Pemasyarakatan” tentu mengandung maksud baik, yaitu pemberian maupun pengayoman warga binaan tidak hanya terfokus pada itikad menghukum (FunitifIntend) saja melainkan suatu berorientasi pada tindakan-tindakan yang lebih manusiawi dan disesuaikan dengan kondisi dari warga binaan itu. Walau istilah pemasyarakatan sudah muncul pada tanggal 5 Juli 1963, namun prinsip-prinsip mengenai pemasyarakatan itu baru dilembagakan setelah berkembangnya konferensi Bina Direktorat Pemasyarakatan di Lembang, Bandung (Jawa Barat) tanggal 27 April 1964 dan dari hasil konferensi dapat disimpulkan bahwa: Tujuan dari pidana penjara bukanlah hanya untuk melindungi masyarakat semata-mata, melainkan harus pula berusaha membina si pelanggar hukum, dimana pelanggar hukum tidak lagi disebut sebagai penjahat, dengan harapan dapat mengambil manfaat sebesarbesarnya dari sistem pemahaman yang diterapkan kepadanya.

Pemasyarakatan dinyatakan sebagai suatu sistem pembinaan terhadap para pelanggar hukum dan sebagai suatu keadilan yang bertujuan untuk mencapai reintegrasi sosial atau pulihnya kesatuan hubungan antara warga binaan pemasyarakatan dengan masyarakat.

Menurut undang-undang Nomor 12 Tahun 1995 tentang pemasyarakatan, pengertian lembaga pemasyarakatan diatur pada pasal 1 ayat 3, yaitu: "Lembaga Pemasyarakatan yang selanjutnya disebut LP adalah tempat untuk melaksanakan pembinaan Narapidana dan anak didik pemasyarakatan. Sehingga, singkatnya LP adalah tempat bagi orang yang dihukum untuk dibina selama menjalani masa hukumannya.

Sistem pembinaan kepada narapidana yang dikenal dengan nama pemasyarakatan, mulai dikenal pada tahun 1964 ketika dalam konferensi Dinas Kepenjaraan di Lembang, tanggal 27 April 1964, Dr. Sahardjo, S.H. melontarkan gagasan perubahan tujuan pembinaan narapidana dari sistem kepenjaraan ke sistem pemasyarakatan. Sebelumnya, Dr. Sahardjo, S.H. telah terlebih dahulu mengemukakan gagasan perubahan tujuan pembinaan narapidana itu, dalam pidato pengukuhannya sebagai Dr. Honoris Causa di Istana Negara tanggal 15 Juli 1963. 
Menurut Sahardjo untuk memperlakukan narapidana diperlukan landasan sistem pemasyarakatan. Inti dari landasan sistem pemasyarakatan tersebut adalah suatu proses pembinaan narapidana yang didasarkan atas asas Pancasila dan memandang narapidana sebagai mahluk Tuhan, individu dan anggota masyarakat sekaligus. Sehingga dapat dikatakan bahwa tujuan dari sistem pemasyarakatan adalah suatu integritas hidup kehidupan dan penghidupan dalam hal ini integritas itu sendiri terdiri dari individu narapidana yang bersangkutan dan masyarakat di luarnya, yang sanggup mengatasi segala tantangan-tantangan hidup dalam mewujudkan, mempertahankan dan menyempurnakan masyarakat yang adil dan makmur berdasarkan pancasila.

Sistem kepenjaraan dalam perkembangannya berubah menjadi sistem pemasyarakatan. Oleh karena itu, pengertian dari sistem pemasyarakatan memasuki babak baru dalam usaha pembinaan narapidana, sehingga perlu sekali sistem pemasyarakatan yang baru ini secara leluasa memperkenalkan diri dan memperjelas keberadaannya kepada masyarakat luas. Sebab, dengan munculnya sistem baru dalam pembinaan narapidana, ternyata masyarakat menganggap sistem pemasyarakatan identik dengan sistem kepenjaraan.

Mengenai pemasyarakatan dan sistemnya, dalam Undang-Undang Nomor 12 tahun 1995 tentang pemasyarakatan, ditegaskan bahwa:

Pemasyarakatan adalah kegiatan untuk melakukan pembinaan warga binaan pemasyarakatan berdasarkan sistem kelembagaan dan cara pembinaan yang merupakan bagian akhir dari sistem pemindahan dalam tata peradilan.

Sistem pemasyarakatan adalah suatu tatanan mengenai arah dan batas suatu cara pembinaan warga pembinaan pemasyarakatan berdasarkan pancasila yang dilaksanakan secara terpadu antara Pembina yang dibina dan masyarakat, untuk meningkatkan kualitas warga binaan agar menghindari kesalahan, memperbaiki diri dan tidak mengulangi tindak pidana sehingga dapat diterima oleh lingkungan masyarakat dan aktif berperan dalam pembangunan dan dapat hidup secara wajar sebagai warga Negara yang baik dan dapat bertanggungjawab. (Undang-undang Nomor 12 Tahun 1995 tentang pemasyarakatan.) 
Pemasyarakatan menurut undang-undang di atas adalah serangkaian usaha untuk mencegah diulanginya perbuatan jahat oleh narapidana juga pembinaan kepada mereka dengan memberikan seperangkat bekal hidup, baik bekal pengetahuan, keterampilan, maupun bekal mental spiritual untuk menambahkan kesadaran mereka, sehingga dapat dan mampu menjadi warga masyarakat Indonesia yang baik dan berguna, serta tanpa diasingkan oleh warga masyarakat lainnya dalam menjalani kehidupannya.

\section{F. Narapidana}

Istilah narapidana diatur dalam undang-undang Nomor 12 tahun 1995 pada pasal 1 ayat ke 5 dan 7 bahwa narapidana masuk warga binaan pemasyarakatan. Dalam pasal tersebut diterangkan bahwa "Warga binaan pemasyarakatan adalah narapidana anak didik pemasyarakatan dan klien pemasyarakatan.(Undang-Undang nomor 12 tahun 1995 tentang pemasyrakatan pasal 1 ayat 5)

Penggolongan warga binaan yang diatur dalam pasal 1 ayat ke 5 tersebut, dibagi e dalam beberapa golongan warga binaan pemasyarakatan, yaitu yang terdapat dalam ayat 7, 8, 9: (Undang-Undang nomor 12 tahun 1995 tentang pemasyarakatan)

1. Narapidana, yakni terpidana yang menjalani pidana hilang kemerdekaan di LP.

2. Anak didik Pemasyarakatan

a. Anak pidana, yaitu anak yang berdasarkan putusan pengadilan menjalani pidana di LP anak paling lama sampai berumur 18 tahun.

b. Anak Negara yaitu anak yang berdasarkan putusan pengadilan diserahkan pada Negara untuk dididik dan ditempatkan di LP anak paling lama sampai berumur 18 tahun.

c. Anak sipil yaitu anak yang atas permintaan orang tua atau walinya memperoleh penetapan pengadilan untuk dididik di LP anak paling lama sampai berumur 18 tahun.

3. Klien Pemasyarakatan adalah seseorang yang berada dalam bimbingan BAPAS 
a. Terpidana bersyarat

b. Narapidana, anak pidana dan anak Negara yang mendapatkan pembebasan bersyarat atau cuti menjelasng bebas.

c. Anak Negara yang berdasarkan putusan pengadilan, pembinaannya diarahkan kepada orangtua asuh atau badan sosial

d. Anak Negara yng berdasarkan Keputusan Menteri atau pejabat di lingkungan direktorat Jenderal Pemasyarakatan yang ditunjuk, bimbingannya diserahkan kepada orangtua asuh atau badan sosial

e. Anak yang berdasarkan penetapan pengadilan, bimbingannya dikembalikan kepada orangtua atau walinya.

\section{G. Metode Penelitian}

Berdasarkan pendekatannya, penelitian ini merupakan penelitian kualitatif dengan berorientasi pada pendekatan kualitatif desktriptif. (Suharsimi Arikunto, 2002: 11) Pendekatan kualitatif deskriptif ini bertujuan untuk menggambarkan keadaan tertentu yang ditempuh melalui penginderaan secara sistematis, faktual, dan akurat mengenai fakta-fakta dan sifat-sifat populasi suatu daerah tertentu.

Dalam penelitian ini peneliti menggunakan deskriptifeksploratif. Dalam pelaksanaan penelitian, peneliti mengamati kegiatan yang dilaksanakan oleh narapidana di dalam LP, ketika mengikuti kegiatan pembinaan keagamaan,. Melalui kegiatan-kegiatan tersebut peneliti dapat menjelaskan keadaan atau status fenomena untuk menggambarkan hal-hal yang berhubungan dengan keadaan sesuatu yakni model pendidikan agama Islam dalam pembinaan mental narapidana di Lembaga Pemasyarakatan Klas I Malang dan Lembaga Pemasyarakatan Wanita Klas II-A Malang.

Lokasi penelitian ini akan dilaksanakan di dua tempat, yaitu:

1. Lembaga Pemasyarakatan Klas I Malang dengan alamat Jl. Asahan No. 7 Malang

2. Lembaga Pemasyarakatan Klas II-A Wanita Malang, Jalan S. Supriadi Sukun Malang 
Dalam penelitian ini, instrumen utama atau instrumen kuncinya adalah peneltiti sendiri. Sedangkan untuk pengumpulan data tetap akan menggunakan instrumen penelitian, diantaranya pedoman wawancara, pedoman pengamatan, pedoman dokumentasi. Untuk pengembangannya, instrumen ini menyesuaikan dengan keadaan di lapangan serta situasi saat peneliti melakukan penelitian.

Dalam pengumpulan data di lapangan, penelitian ini menggunakan 3 prosedur pengumpulan data, yaitu:

1. Metode Observasi,

Dalam penelitian ini, jenis observasi yang digunakan oleh peneliti adalah observasi partisipan, dikarenakan peneliti disini terlibat langsung dan ikut serta dalam kegiatan pembinaan mental melalui pendidikan agama Islam yang dilakukan oleh narapidana di LP Klas I Malang dan LP Wanita Klas II-A Malang.

2. Interview/wawancara

Dalam penelitian yang dilakukan, peneliti lebih cenderung banyak menggunakan wawancara terstruktur, karena dengan wawancara tersebut, peneliti dapat menanyakan pertanyaan dengan lebih sistematis dan tidak terjadi pengulangan pertanyaan yang nantinya dapat menimbulkan jawaban ganda terhadap masalah yang akan di bahas.

3. Dokumentasi

Penggunaan prosedur pengumpulan data dengan dokumentasi yaitu mencari data mengenai hal-hal yang berupa catatan, transkrip, buku, surat kabar, majalah, prasasti, agenda dan sebagainya. (Suharsimi Arikunto, 2002: 231)Metode ini akan digunakan oleh peneliti untuk menggali catatan-catatan tertulis dari LP Klas I Malang dan LP Wanita Klas II-A Malang.

\section{H. Hasil Penelitian}

1. Komponen Input

Materi Pendidikan Agama Islam dalam Pembinaan Mental Warga Binaan di Lembaga Pemasyarakatan di LP Kelas I Malang dan LP Wanita 
Kelas II-A Malang

Berdasarkan temuan dan hasil penelitian, materi pendidikan agama Islam dalam pembinaan mental Warga Binaan di LP Klas I Malang dan LP Wanita Klas II-A Malang, lebih memfokuskan pada materi aqidah dan akhlak. Hal tersebut mengacu pada pandangan bahwa pendidikan yang utama dan pertama yang harus dilakukan adalah pembentukan keyakinan kepada Allah yang diharapkan melandasi sikap, tingkah laku dan kepribadian. (Abdul Majid, 2004: 130)

Tujuan pendidikan agama Islam sebagaimana diungkapkan di atas adalah terbentuknya pribadi muslim, dalam arti manusia yang berakhlak mulia sehingga segala aspek hidup dan kehidupannya sesuai dengan norma-norma agama dan masyarakat. Dengan demikian akan tercapai keharmonisan hubungan antar manusia, untuk menuju kebahagiaan hidup, baik dunia maupun akhirat. Sedangkan tujuan pendidikan akhlak adalah mendorong manusia agar berbuat kebajikan dalam rangka membentuk manusia yang berakhlak mulia. (Abdul Majid, 2004: 130)

Dengan materi aqidah dan akhlak tersebut, para Warga Binaan diharapkan dapat mengintrospeksi diri dan tidak mengulangi perbuatannya lagi. Lebih dari itu, ketika nantinya mereka bebas dari LP, mereka dapat diterima kembali di masyarakat dengan bekal pembinaan yang telah mereka dapat di dalam LP.

Materi akhlak dan aqidah tersebut, adalah materi utama yang diajarkan kepada Warga Binaan, sedangkan sebagai pendukung agar materi tersebut dapat efektif diterima oleh Warga Binaan, maka disampaikan pula materimateri yang mendukung, seperti tuntutan untuk menghormati agama lain dalam hubungan kerukunan antar umat beragama, berzikir, berdoa, mampu menjadi imam atau ceramah kepada sesama Warga Binaan, membaca al Qur'an, belajar Iqra' dan belajar tata cara merawat jenazah.

\section{Komponen Proses}

Model Pembelajaran Pendidikan Agama Islam dalam Pembinaan Mental Warga Binaan di LP Klas I Malang dan LP Wanita Klas II-A Malang

Model pembelajaran pendidikan agama Islam dalam pembinaan mental Warga Binaan di LP Klas I Malang dan LP Wanita Klas II-A Malang, adalah 
simplikasi dari suatu sistem untuk mengajarkan pendidikan agama Islam kepada Warga Binaan. Model pembelajaran PAI yang diterapkan di LP Klas I Malang dan LP Wanita Klas II-A Malang, menggunakan model modifikasi tingkah laku. Penggunaan model tersebut digunakan atas dasar sebagai penguat program pembinaan awal di LP yang bertujuan untuk memberikan seperangkat bekal hidup, baik bekal pengetahuan, keterampilan, maupun bekal mental spiritual untuk menambahkan kesadaran mereka, sehingga dapat dan mampu menjadi warga masyarakat Indonesia yang baik dan berguna, serta tanpa diasingkan oleh warga masyarakat lainnya dalam menjalani kehidupannya Warga Binaan setelah keluar dari LP.

Model modifikasi tingkah laku menekankan pada perilaku yang terobservasi metode bagaimana memanipulasi penguatan atau reinforcement. Menekankan pada aspek perubahan perilaku psikologis dan perilaku yang tidak dapat diamati. Beberapa model pembelajaran yang tergolong didalamnya adalah mastery learning, manajemen kontingensi, kontrol diri, dan pembelajaran keterampilan. (AM Akim Sumarno, 2012)

Seringnya para mantan Warga Binaan yang melakukan tindakan kejahatan yang sama, bisa juga dipengaruhi oleh lingkungan yang ada di masyarakat, dikarenakan tidak adanya dukungan dari masyarakat untuk mendukung perubahan perilaku mantan Warga Binaan tersebut. Dengan adanya materi akhlak dan aqidah yang disampaikan dalam pembinaan agama di LP, diharapkan Warga Binaan dapat membentuk perilaku yang bisa lebih baik.

\section{Komponen Output: Psikomotorik, Afektif, Kognitif}

Dalam proses pelaksanaan pendidikan semua unsur di atas perlu mendapatkan perhatian. Pembelajaran pendidikan agama Islam yang dilaksanakan Warga Binaan LP, yang meliputi pembelajaran yang telah terjadwal mecakup aspek kognitif, afektif dan psikomotorik. Ketiga aspek tersebut secara terpadu ditanamkan pada Warga Binaan, sehingga setelah Warga Binaan mengikuti kegiatan pembelajaran, wujud nyata dari ketiga aspek tersebut dapat diekspresikan dalam sikap perilaku sehari-hari dan sekaligus sebagai hasil yang dimiliki Warga Binaan setelah belajar / bebas dari LP. 
Sebagai ilustrasi umum hasil (kemampuan) yang dimiliki Warga Binaan adalah:

1. Aspek Kognitif

a. Menguasai dasar aqidah dan ibadah

b. Mampu memahami dan berpikir lebih mendalam tentang arti sebuah kehidupan.

c. Mampu mengembangkan ide-ide kreatif.

d. Mampu membaca al Quran / Iqra' dengan benar

e. Dapat membaca aktif dan pasif serta memahami isi kitab yang dikaji di LP

2. Aspek Afektif

Dengan pembinaan, bimbingan dan kegiatan pembelajaran yang dilaksanakan Warga Binaan di LP, menurut penilaian petugas LP, warga binaan di LP telah menunjukkan sifat-sifat sebgai berikut:
a. Berakhlak al-karimah
b. Disiplin dan tanggungjawab dan penuh pengabdian
c. Memiliki jiwa solidaritas dan toleransi
d. Percaya diri dan menghargai orang lain.
e. Tawadhu
f. Menjalin komunikasi dengan baik dengan sesama warga binaan maupun petugas dan Pembina agama

3. Aspek Psikomotorik

Dalam aspek ini kemampuan yang dicapai Warga binaan di LP adalah:
a. Istiqomah (konsisten) dalam melaksanakan ibadah
b. Fasih membaca Iqra' dan al Quran
c. Terampil dalam mengembangkan kegiatan yang di laksanakan LP.
d. Memiliki kemampuan dan keberanian berceramah
e. Mengadakan bimbingan tutor sebaya
f. Memiliki kreatifitas yang banyak. 
Mantan warga binaan dengan kemampuan yang dimiliki ada yang mengamalkan ilmunya dan diterima kembali dengan baik di masyarakat. Pada dasarnya setiap Warga Binaan memiliki fungsi heriditas yang harus dikembangkan secara maksimal untuk keberhasilan pegemangan potensi warga binaan.

\section{Penutup}

Berdasarkan paparan data dan diskusi hasil penelitian di atas, maka dapat ditarik kesimpulan bahwa:

1. Materi pendidikan agama Islam yang disampaikan kepada narapidana di LP Klas I Malang dan LP Wanita Klas II-A Malang adalah tentang keimanan (ketauhidan), dan akhlak;

2. Model pendidikan agama Islam dalam pembinaan mental narapidana yang dilakukan di LP Klas I Malang dan LP Wanita Klas II-A Malang adalah model modifikasi tingkah laku.

3. Kondisi mental narapidana setelah diadakannya proses model pembelelajaran PAI di LP Klas I Malang dan LP Wanita Klas II-A Malang, memiliki perkembangan yang sesuai dengan visi misi dari kedua LP tersebut, diantaranya warga binaan berakhlak baik, memiliki disiplin dan tanggugjawab serta penuh pengabdian, memiliki jiwa solidaritas dan toleransi, lebih percaya diri dan selalu menghargai orang lain, tawadhu', selalu menjalin komunikasi dengan baik dengan sesama warga binaan maupun petugas dan Pembina agama.

\section{Daftar Pustaka}

Abdul Majid dan Dian Andayani. 2004. Pendidikan Agama Islam Berbasis Kompetensi Konsep dan Implementasi Kurikulum, Bandung: Remaja Rosdakarya.

Bruce Joyce,dkk. 2009. Model of Teaching: Model-Model Pengajaran. Yogyakarta: Pustaka Pelajar. 
David J. Cooke, dkk. 2008. Menyingkap Dunia Gelap Penjara. Jakarta: PT. Gramedia Pustaka Utama.

Dokumen Resmi. Data Telegram Isi LP wanita Malang Dan Jenis Kejahatan Tanggal 31 Januari 2012.

Kholil Lur Rochman. 2010. Kesehatan Mental. Yogyakarta: Fajar Media Press.

Muhaimin, et, al., 2001. Paradigma Pendidikan Islam, Upaya Mengefektifkan Pendidikan Agama Islam Di Sekolah.

Suharsimi Arikunto, 2002. Prosedur Penelitian Suatu Pendekatan Praktek, Jakarta: Rineka Cipta.

Undang-Undang Nomor 12 tahun 1995 tentang pemasyarakatan.

Zakiah Daradjat. 1971. Islam dan Kesehatan Mental. Jakarta: Gunung Agung 
